\title{
Exocrine pancreatic function in diabetes mellitus
}

\author{
P DANDONA, DB FREEDMAN, Y FOO, J PERKINS, A KATRAK, DP MIKHAILIDIS, \\ SB ROSALKI, AG BECKETT
}

\begin{abstract}
From the Department of Chemical Pathology, Royal Free Hospital and School of Medicine, Pond Street, London
\end{abstract}

SUMMARY An investigation of serum immunoreactive trypsin concentration and pancreatic isoamylase activity in patients with diabetes mellitus has shown that exocrine pancreatic deficit is maximal in insulin dependent diabetics, intermediate in those controlled with sulphonylureas, and absent in patients controlled with biguanides or diet or both. A significant correlation between the serum concentrations of both these pancreatic enzymes and $C$ peptide was found. Serum pancreatic enzyme concentrations were not related to glycosylated haemoglobin concentrations, the dosage of insulin, or the age of onset of diabetes. The concentration of immunoreactive trypsin was found to be low in most of the insulin dependent diabetics in whom this enzyme was measured at the time of the clinical onset of diabetes. Thus exocrine pancreatic deficit in diabetes closely parallels the endocrine $\beta$ cell deficit and occurs concurrently with, or antedates, the clinical presentation of type I diabetes. It is therefore possible that in type I diabetes similar mechanisms are entailed in the pathogenesis of impaired endocrine and exocrine pancreatic function.

Exocrine pancreatic function is impaired in insulin dependent diabetics. This conclusion is supported by direct measurement of pancreatic enzyme concentrations in duodenal aspirates ${ }^{1}$ and by the finding of low serum concentrations of immunoreactive tryp$\sin ^{23}$ and pancreatic isoamylase activity ${ }^{4}$ in such patients. Measurement of these pancreatic enzymes in the serum also showed diminished exocrine pancreatic reserve in diabetics treated with sulphonylureas but not in those controlled by biguanides or diet. ${ }^{24}$ These results suggested correlation of exocrine and endocrine pancreatic reserve.

The present study confirms such a correlation and also assesses the pancreatic exocrine deficit in relation to the clinical onset of insulin dependent diabetes. The effect of duration, age of onset, and quality of control of diabetes on exocrine pancreatic function was also studied.

\section{Patients, material and methods}

Eighty seven diabetic patients were studied: 44 insulin dependent diabetics, 27 patients controlled with sulphonylureas (with or without biguanides), and 16 patients treated with biguanides or diet alone. Fif-

Accepted for publication 23 November 1983 teen of the insulin dependent diabetics were investigated at the time of clinical onset of diabetes. Six patients were studied at a stage when they had ceased to respond to oral hypoglycaemic agents and were due for a change in insulin treatment.

Four patients had immunoreactive trypsin concentrations measured in samples obtained on admission to hospital, a week later, and at least six weeks after an acute episode of diabetic ketoacidosis.

Serum samples were obtained from these patients between 10.00 and $11.00 \mathrm{am}$, before their morning dose of insulin or drugs and breakfast. The samples were frozen immediately at $-40^{\circ} \mathrm{C}$ until they were assayed for immunoreactive trypsin and pancreatic isoamylase. Another sample of heparinised plasma was also obtained and stored at $4^{\circ} \mathrm{C}$ until haemoglobin $A_{1}$ concentration was measured (within $24 \mathrm{~h})$.

Immunoreactive trypsin concentration was measured in all sera as previously described, using a radioimmunoassay kit (Hoechst, UK) ${ }^{2}$ Pancreatic isoamylase activity was measured in 37 sera by the electrophoretic separation of amylase isoenzymes. ${ }^{\circ}$ $C$ peptide concentration was measured in 33 sera using a RIA kit (Novo, Denmark). ${ }^{7}$ Haemoglobin $A_{1}$ concentrations were measured in 37 sera by the chromatographic separation of haemoglobin $A_{1}$ on Biorex microcolumns (Isolab) as previously 
described. ${ }^{8}$

Statistical comparisons were made using Student's unpaired $t$ tests.

\section{Results}

INSULIN DEPENDENT DIABETICS (Fig. 1)

Immunoreactive trypsin concentration was below the lower reference limit $(140 \mu \mathrm{g} / \mathrm{l})$ in 27 of 44 insulin dependent diabetics. The mean value of this group was $136 \pm 26 \mu \mathrm{g} / 1$ (mean $\pm 1 \mathrm{SD}$ ), which was significantly lower than that found in 96 normal healthy controls $(272 \pm 66 \mu \mathrm{g} / \mathrm{l} ; \mathrm{p}<0.001)$ and also significantly lower than that found in diabetic patients treated with sulphonylureas $(199 \pm 34 \mu \mathrm{g} / \mathrm{l}$; $\mathrm{p}<0.001)$. Pancreatic isoamylase activity was below normal in nine of $20(48 \%)$ insulin dependent diabetics, and the mean of this group $(79 \pm 1.3 \mathrm{U} / \mathrm{l})$ was significantly lower than that in 97 healthy controls $(115 \pm 27 \mathrm{U} / \mathrm{l} ; \mathrm{p}<0.01)$. In 15 patients with insulin dependent diabetes of recent onset immunoreactive trypsin concentration was below normal in $11(73 \%)$, a proportion similar to that found in the 44 insulin dependent diabetics described above. Three of six patients in whom sulphonylurea treatment had failed and who were changed to insulin treatment had serum

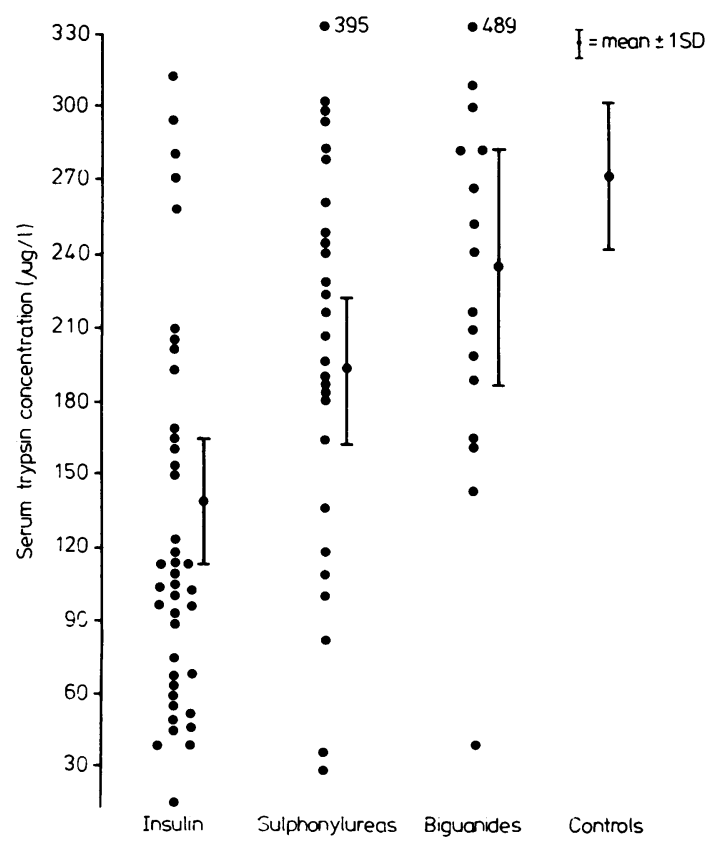

Fig. 1 Serum immunoreactive trypsin concentrations in diabetic patients. immunoreactive trypsin concentrations below normal. The mean concentration in these six patients $(153 \pm 16 \mu \mathrm{g} / \mathrm{l})$ was not significantly different from that in patients controlled with sulphonylureas but was significantly lower than that in controls $(p<$ $0 \cdot 01)$.

\section{PATIENTS TREATED WITH SULPHONYLUREAS}

Patients controlled with sulphonylureas had a mean serum immunoreactive trypsin concentration of 199 $\pm 34 \mu \mathrm{g} / \mathrm{l}$ (mean $\pm \mathrm{SD}$ ), which was significantly lower $(p<0.001)$ than that in controls. Seven of 27 patients $(26 \%)$ in this group had serum immunoreactive trypsin concentrations below normal. Mean pancreatic isoamylase activity in patients treated with sulphonylureas $(72 \pm 30 \mathrm{U} / \mathrm{l})$ was significantly lower than that in controls $(p<0.02)$. Pancreatic isoamylase activity was lower than nor$\mathrm{mal}$ in two of 12 patients in this group.

\section{PATIENTS TREATED WITH BIGUANIDES OR DIET}

The mean serum immunoreactive trypsin concentration in patients controlled with biguanides or diet $(233 \pm 53 \mu \mathrm{g} / \mathrm{l})$ was not significantly different from that in controls. Only one patient of $16(6 \%)$ in this group had a serum immunoreactive trypsin concentration lower than normal. This patient also had a serum pancreatic isoamylase activity below normal. The mean serum pancreatic isoamylase activity ( 115 $\pm 33 \mathrm{U} / \mathrm{l})$ in this group was not significantly different from that in controls.

\section{EFFECT OF KETOACIDOSIS (Table)}

In four patients serum immunoreactive trypsin concentration was measured during and after an episode of diabetic ketoacidosis. In two of these patients immunoreactive trypsin concentrations before the episode of ketoacidosis were also available. Serum immunoreactive trypsin concentration fell sharply during ketoacidosis but returned to the basal value six to eight weeks after the stabilisation of diabetes. The basal serum concentrations of immunoreactive trypsin in both patients were below normal.

Serum trypsin concentrations in new diabetics with ketoacidosis

\begin{tabular}{lll}
\hline Patient no & \multicolumn{2}{l}{ Serum trypsin concentration $(\mu \mathrm{g} / \mathrm{l})$} \\
\cline { 2 - 3 } & Before control & After control \\
\hline 1 & 32 & 118 \\
2 & 45 & 95 \\
3 & 50 & 120 \\
4 & 68 & 132 \\
\hline
\end{tabular}

*After control serum samples taken six to eight weeks after stabilisation with insulin. 


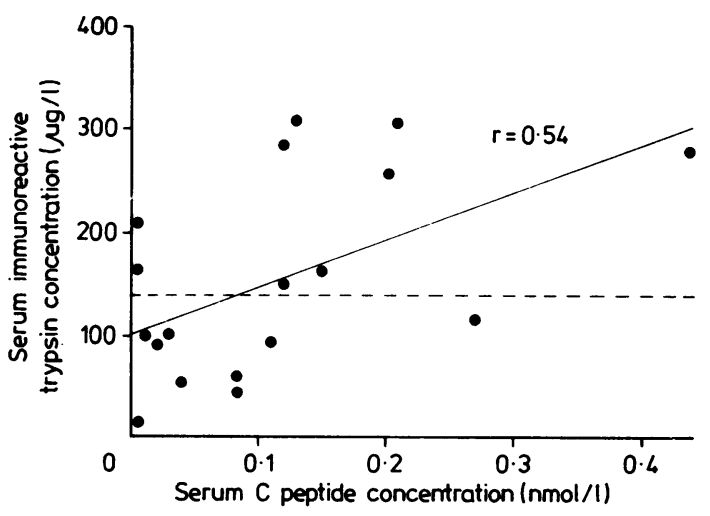

Fig. 2 Correlation between serum immunoreactive trypsin concentration and $C$ peptide concentration in insulin dependent diabetics.

\section{PEPTIDE CONCENTRATIONS}

$C$ peptide concentration was lower than normal (less than $0.14 \mathrm{nmol} / \mathrm{l}$ ) in $80 \%$ of insulin dependent diabetics; in one patient it was unexpectedly high. All patients treated with sulphonylureas had concentrations well within the normal reference range $(0 \cdot 14-0.5 \mathrm{nmol} / \mathrm{l})$. There was a significant correlation $(r=0.54 ; n=18 ; p<0.01)$ between serum immunoreactive trypsin and $C$ peptide concentration in insulin dependent diabetics (Fig. 2). A correlation between pancreatic isoamylase activity and $\mathrm{C}$ peptide concentration $(r=0.59 ; p<0.01)$ was also found (Fig. 3); this correlation was found even when insulin dependent diabetics and sulphonylurea treated patients were pooled together $(r=0.6 ; n=$ $30 ; p<0.01$; Fig. 4). The correlation between $C$ peptide immunoreactive trypsin concentration and

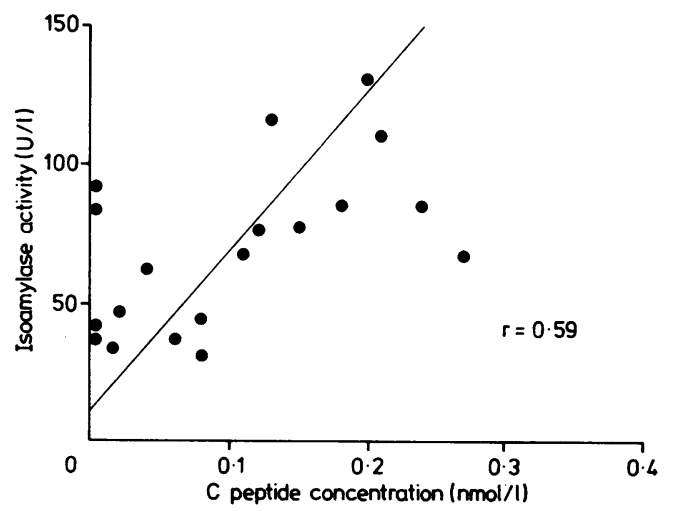

Fig. 3 Correlation between pancreatic isoamylase activity and $C$ peptide concentration in insulin dependent diabetics.

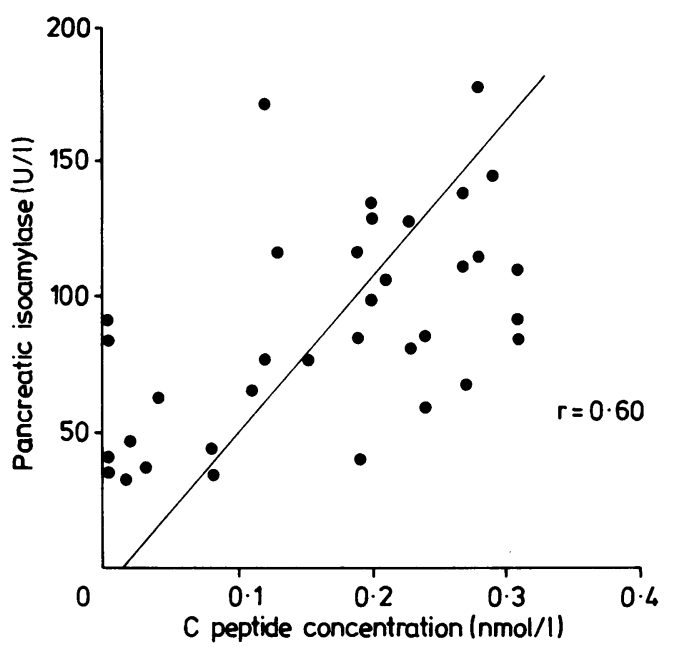

Fig. 4 Correlation between pancreatic isoamylase activity and $C$ peptide concentration in diabetic patients.

pancreatic isoamylase activity in insulin dependent diabetics did not alter even if the patient with the unexpectedly high $\mathrm{C}$ peptide concentration was excluded. The high $\mathrm{C}$ peptide concentration found in this patient may be due to the fact that he was not a true insulin dependent diabetic and that the decision to treat him with insulin was based on some clinical reasons. The normal $\mathrm{C}$ peptide concentrations in some of the other insulin dependent diabetics could have been due to interference by proinsulin, since no attempt was made to separate proinsulin before the radioimmunoassay of $C$ peptide.

\section{GLYCOSYLATED HAEMOGLOBIN A,}

Haemoglobin $A_{1}$ concentrations were higher in insulin dependent diabetics (mean 11.6 $\pm 1.8 \%$ ) than in patients treated with sulphonylureas $(9.7 \pm 0.9 \%)$ and controls $(7 \cdot 1 \pm 0.7 \%)$. Mean haemoglobin $A_{1}$ concentration in the patients treated with biguanides or diet was unexpectedly high, with a wide scatter $(11.5 \pm 3 \cdot 2 \%)$. There was no significant correlation between haemoglobin $\mathbf{A}_{1}$ concentration, immunoreactive trypsin concentration, or pancreatic isoamylase activity.

There was no correlation between the age of onset, the duration of diabetes, or the age of the patients and immunoreactive trypsin concentration or pancreatic isoamylase activity in either insulin dependent or non-insulin dependent diabetics.

\section{Discussion}

The data presented here confirm our previous 
finding that immunoreactive trypsin concentrations and pancreatic isoamylase activities are significantly reduced in insulin dependent diabetics and slightly, but also significantly, reduced in patients controlled with sulphonylureas. ${ }^{12}$ They are also consistent with the significantly lower pancreatic lipase activities in sera of diabetic patients when compared with controls. ${ }^{9}$ The present study has shown that there is a significant correlation between the pancreatic enzyme activities and $C$ peptide concentration. There is thus a parallelism between the reduction in endocrine and exocrine pancreatic function, although the decreased endocrine function is much more pronounced than the decreased exocrine function. This is the converse of what we have recently shown in patients with cystic fibrosis ${ }^{10-12}$ and $\beta$-thalassaemia major with iron overload, ${ }^{13}{ }^{14}$ in whom the main target of damage is the exocrine pancreatic tissue and the evidence of endocrine injury, ${ }^{15-17}$ though present, is less pronounced.

The correlation between the endocrine and exocrine function in diabetes mellitus suggested that the fall in exocrine reserve might be the result of diabetes and lack of insulin. Such an interpretation is supported by the fact that insulin stimulates the secretion of enzymes by pancreatic acinar cells. ${ }^{18}$ Although the concentrations of insulin required to exert this effect are extremely high, it could be argued that such concentrations probably do exist in the vicinity of the islets of Langerhans, owing to local diffusion of hormone from $\beta$ cells. Furthermore, pancreatic acinar cells have recently been shown to possess insulin receptors. ${ }^{19}$

Most of the insulin dependent diabetics (73\%) investigated at the time of onset of diabetes, however, had considerably reduced serum immunoreactive trypsin concentrations; it is therefore likely that the exocrine deficit is not a consequence of lack of insulin or diabetes, but that a common pathological process simultaneously affects the endocrine and exocrine components of the pancreas. Further investigation of exocrine pancreatic reserve in populations at risk of developing diabetes will clarify this point. Our preliminary studies on families which include two or more diabetics have shown evidence of exocrine pancreatic injury in the absence of glucose intolerance (unpublished data). If indeed this observation is confirmed on further investigation of subjects genetically predisposed to develop diabetes, it may imply that a part of the genetic susceptibility manifests itself as a diminution in the active acinar mass of the pancreas. Clearly, further studies are required in this direction.

A third possible mechanism which may contribute to diminished exocrine pancreatic function is autonomic neuropathy, since vagal stimulation facilitates the secretion of pancreatic enzymes. In a recent study on exocrine pancreatic reserve in vagotonised patients, however, we found only minimal abnormalities of pancreatic function. ${ }^{20}$ Furthermore, autonomic neuropathy would not account for the abnormalities found at the time of clinical presentation of diabetes.

Another possible factor which may account for the diminished exocrine pancreatic function and hence the low pancreatic enzyme activity in sera of diabetic patients is human pancreatic polypeptide. Pancreatic polypeptide concentration is raised in diabetics (more so in insulin dependent diabetics), ${ }^{21}$ and, furthermore, it inhibits pancreatic enzyme secretion. $^{22} \mathrm{~A}$ raised human pancreatic polypeptide concentration, however, does not necessarily lead, in the long term, to a suppression of pancreatic enzyme concentrations in serum. In a recent study on elderly subjects we found a considerable increase in serum immunoreactive trypsin concentration and pancreatic lipase activity, ${ }^{23}$ although they had raised pancreatic polypeptide concentrations in their sera. ${ }^{21}$ Conversely, suppressed pancreatic polypeptide concentrations, as in vagotomised patients, ${ }^{24}$ are not associated with any alteration in the pattern of pancreatic enzyme concentrations in serum. ${ }^{20}$ Thus there is no consistent relation between serum human pancreatic polypeptide concentrations and pancreatic enzymes.

Some doubt has recently been expressed regarding the importance of raised immunoreactive trypsin concentrations since some patients without evidence of pancreatic dysfunction have increased values. Low immunoreactive trypsin concentrations, however, do relate to diminished exocrine pancreatic reserve. ${ }^{25}$ Immunoreactive trypsin concentration has been shown by us previously to be low or absent in adults with cystic fibrosis. ${ }^{9}$ We have also found low immunoreactive trypsin concentrations in older patients with thalassaemia and iron overload. ${ }^{10}$ Furthermore, our previous observations on immunoreactive trypsin concentrations in insulin dependent diabetics are similar to those of Frier $e t$ al based on trypsin activity of duodenal aspirates.' Finally, in three randomly selected insulin dependent diabetics of our own series of patients with low immunoreactive trypsin concentrations, the duodenal aspirate tryptic activity was also low. It has also been shown that pancreatic enzyme activity in serum parallels enzyme activity in duodenal aspirates. ${ }^{26}$ Low concentrations of pancreatic enzymes in serum thus reflect diminished pancreatic reserve.

This study has shown that the quality of glucose homeostasis, as reflected by haemoglobin $\mathrm{A}_{1}$ concentrations, did not affect serum immunoreactive trypsin or pancreatic isoamylase in insulin depen- 
dent diabetics. In this respect, our findings differ from those of Frier et al, who found a correlation between tryptic activity in duodenal aspirates and the quality of diabetic control. ${ }^{1}$ Their criteria for diabetic control, however, were mainly clinical and were based on isolated blood glucose measurements; haemoglobin $A_{1}$ measurements were not carried out. These authors also found that a younger age of onset, a longer duration of diabetes, and an increasing age independently led to a diminution in the exocrine pancreatic reserve of insulin dependent diabetics. We did not find such a correlation and neither did Adrian et al, who found significantly lower immunoreactive trypsin concentrations in young insulin dependent diabetics. ${ }^{3}$

Diabetic ketoacidosis produced a considerable temporary reduction in immunoreactive trypsin concentration. This could be due to a combination of a general catabolic state and acute lack of insulin, both of which are reversed after adequate treatment.

In conclusion, the degree of impairment of exocrine pancreatic function, as reflected in serum immunoreactive trypsin concentration and pancreatic isoamylase activity, paralleled the reduction in $\beta$ cell function in diabetics in general and in insulin dependent diabetics in particular. Since the impairment was also present at the time of clinical onset of diabetes, it is possible that the mechanisms underlying the injury to the $\beta$ cell-genetic, autoimmune, and viral-may also be relevant to the impaired function of the pancreatic acinar cell.

\section{References}

' Frier BM, Saunders JHB, Wormsley KG, Bouchier IAD. Exocrine pancreatic function in juvenile onset diabetes mellitus. Gut 1976;17:685-91.

${ }^{2}$ Dandona P, Elias E, Beckett AG. Serum trypsin levels in diabetes mellitus. $\mathrm{Br}$ Med J 1978;ii: 1125-6.

${ }^{3}$ Adrian TE, Barnes AJ, Bloom SR. Hypotrypsinaemia in diabetes mellitus. Clin Chim Acta 1979;79:213-6.

${ }^{4}$ Foo Y, Rosalki SB, Ramdial L, Mikhailidis DP, Dandona P. Serum isoamylase activities in diabetes mellitus. J Clin Pathol 1980;33:1102-5.

${ }^{5}$ Skoha J, Stephan J, Havranek T, et al. Isoamylase in diabetes mellitus. Diabetologia 1981;20:129-33.

- Rosalki SB. A direct staining technique for amylase isoenzyme demonstration. J Clin Pathol 1970;23:373-4.

' Heding LG. Radioimmunological determination of human C-peptide in serum. Diabetologia 1975;11:541-8.

${ }^{8}$ Dandona P, Freedman DB, Moorhead JF. Glycosylated haemoglobin in chronic renal failure. $\mathrm{Br}$ Med J 1979;i:1183-4.
- Junglee D, deAlbarran R, Katrak A, Freedman DB, Beckett AG, Dandona P. Serum pancreatic lipase activity in diabetes mellitus. J Clin Pathol 1983;36:200-2.

${ }^{10}$ Dandona P, Hodson ME, Ramdial L, Batten JC. Serum immunoreactive trypsin concentrations in cystic fibrosis. Thorax 1981;38:60-2.

" Foo Y, Rosalki SB, Hodson ME, Batten JC, Dandona P. Serum pancreatic isoamylase in cystic fibrosis. In: Sturgess JM. Perspectives in cystic fibrosis. Proceedings of the eighth international congress of Cystic Fibrosis. Toronto: Canadian Cystic Fibrosis Foundation, 1980:10a.

12 Junglee D, Penketh A, Katrak A, Hodson M, Batten JC, Dandona $\mathrm{P}$. Serum pancreatic lipase activity in cystic fibrosis. $\mathrm{Br}$ Med J 1983;286: 1693-5.

${ }^{13}$ Hussian M, Dandona P, Fedail M, Flynn D, Hoffbrand V. Serum immunoreactive trypsin in thalassaemia major. J Clin Pathol 1981;34:970-1.

14 Junglee D, Katrak A, Hoffbrand V, Dandona P. Serum pancreatic lipase in $\beta$-thatassaemia major. Clin Chem 1983; 29:2003-4.

is Dandona P, Hodson ME, Perkins J, Bell J, Batten JC. Serum C peptide concentrations in cystic fibrosis. In: Sturgess JM. Per-

- spectives in cystic fibrosis. Proceedings of the eighth international congress of Cystic Fibrosis. Toronto: Canadian Cystic Fibrosis Foundation, 1980: 10a.

${ }^{16}$ Dandona $\mathrm{P}$, Hodson M, Batten JC. $\beta$-cell reserve in cystic fibrosis. J Clin Pathol 1983;36:790-2.

17 Dandona P, Hussain M, Vargehese Z, Politis D, Flynn D, Hoffbrand V. Insulin resistance and iron overload. Ann Clin Biochem 1983;20:77-9.

${ }^{18}$ Kanno T, Saito N. The potentiating influences of insulin on pancreozymin induced hyperpolarisation and amylase release in the pancreatic acinar cell. J Physiol 1976;261:505-21.

${ }^{19}$ Korc M, Sankaran H, Wank KY, Williams JA, Goldfine ID. Insulin receptors in isolated mouse pancreatic acini. Biophys Biochem Res Comm 1978;84:293-9.

${ }^{20}$ Mikhailidis DP, Foo Y, Ramdial L, Kirk RM, Rosalki SB, Dandona $P$. Pancreatic exocrine function after truncal and highly selective vagotomy. J Clin Pathol 1981;34:963-4.

${ }^{21}$ Floyd JC, Fajans SS, Pek S, Chance RE. A newly recognised pancreatic polypeptide; plasma levels in health and disease. Rec Prog Horm Res 1977;33:519-70.

${ }^{22}$ Lin TM, Chance RE. Candidate hormones of the gut. Gastroenterology 1974;67:730-55.

${ }^{23}$ Mohiuddin J, Junglee D, Katrak A, Green M, Dandona P. Serum pancreatic lipase in the elderly. Ann Clin Biochem 1984 (in press).

${ }^{24}$ Glaser B, Vinik AI, Valtysson G, Zoghlin G. Truncal vagotomy abolishes the somatostatin response to insulin induced hypoglycaemia in man. $J$ Clin Endocrinol 1981;52:823-5.

${ }^{25}$ Ruddell WS, Mitchell CJ, Hamilton I, Leek JP, Kelleher J. Clinical value of serum immunoreactive trypsin concentration. $\mathrm{Br}$ Med J 1982;283:1429-32.

${ }^{26}$ Magid E, Horsing M, Rune SJ. On the quantitation of isoamylases in serum and the diagnostic value of serum pancreatic type amylase in chronic pancreatitis. Scand J Gastroenterol 1977;12:621-7.

Requests for reprints to: Dr P Dandona, Metabolic Unit, Department of Chemical Pathology, Royal Free Hospital, London NW3 2QG, England. 